\title{
A HEALTHY DOSE OF PESSIMISM? INFLUENCE OF THE UKRAINIAN ECONOMY ON ITS BANKING SECTOR CREDIT RATINGS
}

\author{
Svitlana POKRASON ${ }^{1}$ \\ Kyiv National Economic University named after Vadym Hetman, Ukraine
}

\begin{abstract}
The purpose of the research is to identify the influence of Ukraine's economic development on the international agencies' credit rating of its banking system. The instability and ambiguous geopolitical position of Ukraine are complicating any predictions for its economic developments. In the meanwhile, massive restructuring of all sectors of the economy became the necessary minimum for the reformation of the country and the achievement of the international standards. It is interesting to see how exactly these international standards, as represented by the evaluation of the rating agencies, appraise Ukraine, and particularly its banking sector. Themethodology involves the analysis of the three major Ukrainian banks - PrivatBank, Oschadbank, and Ukreximbank using Fitch's credit quality assessment systematic as an example. The comparative analysis was performed using Tier 1 capital ratio and loan-to-deposit ratio of these banks, year-to-year quarterly GDP growth, consumer price index (CPI) year-to-year change, UAH/USD exchange rate, 2-year and 5-year government bond yield, as well as 2-year and 5 -year credit default swap (CDS). Results show that the most influential credit rating drivers for Ukrainian banks are: exchange rate; funding and liquidity; capital position and asset quality; sovereign risk. The research showed that the 2-year and 5-year government bond yield in USD and 2-year and 5-year CDS were influenced by similar trends. The yield on short-dated Ukrainian governmental bonds has shown a parallel increase with the corresponding CDS that indicated the market's evaluation of the stressed condition of the country's government and economy. Additionally, conventional yield structures displayed inversed nature with 2-year governmental bond yield in USD trading at significantly higher yields than 5 -year government bond yield in USD during times of economic distress. Although longer maturity instruments should usually trade at a higher rate, such a development could have reflected the public markets'scepticism to the Ukrainian government's short-term solvency. The closer look at the Tier 1 capital ratio, which is considered to be a key indicator of the financial health of the banks, revealed analogy between it and three major Ukrainian banks rating development, indicating the Tier 1 capital ratio as a strong influencing factor. Loan-to-deposit ratio as an indicator of bank liquidity moved in parallel with decreasing credit ratings. The strong decrease in the UAH/USD exchange rate mirrored a strong increase in inflation and overall worsening state of the Ukrainian economy also being reflected in the major banks' ratings. Practical implications. The correlation of these factors is relevant for bank managers and investors who can use financial market indicators to forecast and plan their own ability to conduct business. Likewise, academic researchers can further build on this study to add to the literature on country-specific reviews of sovereign debt crises and their impact on national banking systems. Value/originality. This research demonstrates that a worsening of financial indicators of the health of Ukraine's financial system as measured by government bond yields and the trading of credit default swaps, as well as the country's economic downturn, go along with a decline of local banks' credit ratings.
\end{abstract}

Key words: banking sector, default, credit rating, rating agency, restructuring, economic downturn, sovereign risk, funding and liquidity, capital position, asset quality.

JEL Classification: F62, G01, G21, G24, G28, G33

\section{Introduction}

The continuously stressed condition of the Ukrainian economy has had a strongly negative impact on the country's banking sector. Currently, the ability of Ukraine's government to meet the ambitious fiscal and economic targets, agreed with the IMF to secure access to further liquidity, is closely being monitored by market participants. While the agreement between the government and creditors holding USD 18 bn of government and government-guaranteed Eurobonds is cautiously seen as a positive sign, with market prices of Ukrainian government bonds appreciating questions

Corresponding author:

${ }^{1}$ Department of Corporate Finance and Controlling, Kyiv National Economic University named after Vadym Hetman.

Email:spokrason@gmail.com 
about further needed restructuring measures are being raised. All the while, political conflict within the country is ongoing.

For a business model as integrally based on leverage as banking, these developments are understandably threatening: volatility in the main interest rate, political uncertainty, rapidly fluctuating deposit levels, as well as the dramatic decline in the hryvnia exchange rate against the main foreign currencies are presenting tough challenges. Combined with a rapid increase in nonperforming loans due to declining credit quality in both the commercial and retail markets, these developments have been putting a critical strain on the country's banks and further threaten to erode their capital positions.

The purpose of this research is to identify the influence of the country's economic development on the international agencies' credit rating of its banking system. The study methodology involves the analysis of the three major Ukrainian banks - PrivatBank, Oschadbank, and Ukreximbank using Fitch's credit quality assessment systematic as an example. For the comparison, the Tier 1 capital ratio of the Ukrainian banks, 2-year and 5-year CDS, 2-year and 5-year government bond yield, loan to deposit ratio of the Ukrainian banks, year-to-year quarterly GDP growth, CPI year-to-year change and UAH/USD exchange rate were taken.

First, the development of Ukrainian macroeconomic indicators is analysed. Second, the historical Fitch ratings issuer default rating development for PrivatBank, Oschadbank, and Ukreximbank is presented. Third, the development of the Ukraine's 2-year and 5-year governmental bond yield in USD and 2-year and 5-year CDS is closely looked into, which could provide the indication of the potential default risks. Further, the Ukrainian bank ratings are being compared versus quarterly real GDP development, Tier 1 capital ratio development of Ukrainian banks, loan to deposit ratio development of Ukrainian banks, and UAH/USD exchange rate development.

2. Ukrainian macroeconomic indicators and banks' credit ratings development

From Figure 1, it can be seen that due to the economic crisis and political uncertainty the country was hit by the sharp increase in inflation starting at the beginning of May 2014 with the CPI reaching growth rates above $60 \%$ in April 2015. The Ukrainian Central Bank reacted to this through a strong increase in the discount rate up to $30 \%$. A painful decline in the exchange rate of up to 30 UAH per USD in February 2015 reflected the strong inflation and since then has been strongly counteracted by the National Bank of Ukraine, as of October 2017 stabilizing around $26 \mathrm{UAH}$ per USD, and discount rate going down to $12.5 \%$. GDP growth reached the quarterly rate of minus $17 \%$ in March 2015 and improving to $2.3 \%$ in the second quarter of 2017.

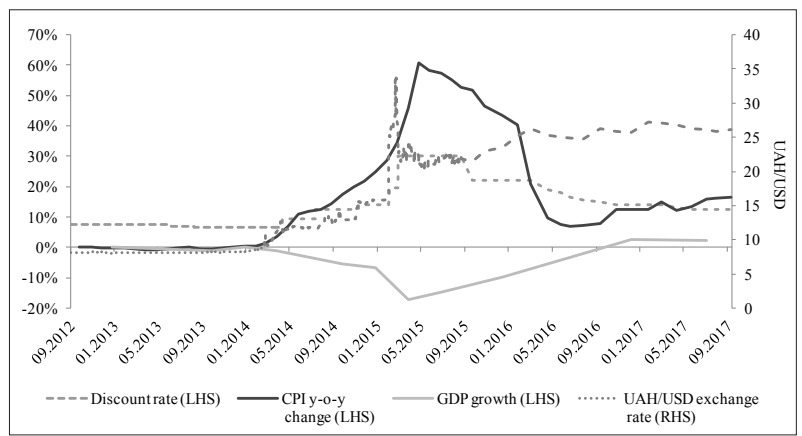

Fig. 1. Ukrainian macroeconomic indicators development, 2012-2017

Source: the author's own research based on data of the National Bank of Ukraine (2017)

These developments have been reflected in the banks' broadly declining credit ratings. While a direct cause and effect relationship between credit ratings and banks' refinancing risks, as well as capital costs is difficult to establish, major bond issuances, especially those marketed to international investors, usually require a rating by a market-leading agency and international asset managers often are operating under certain investment restrictions with respect to certain rating levels.

Therefore, credit rating levels continue to have strong implications for the ability of banks to access refinancing markets, as well as their overall cost of capital, reflecting the market's increased perception of risk for the Ukrainian economy as a whole and the banking sector in particular.

Looking at the long-term issuer default ratings of the country's three largest lenders, PrivatBank, Oschadbank, and Ukreximbank, as determined by Fitch, there has been a steady decline until the second quarter of 2015 . Banks' rating downgrades started in September 2013, preceding the decline of macroeconomic indicators (see Figure 1). Rating improvements for Oschadbank and Ukreximbank started in Q3 2015, following the

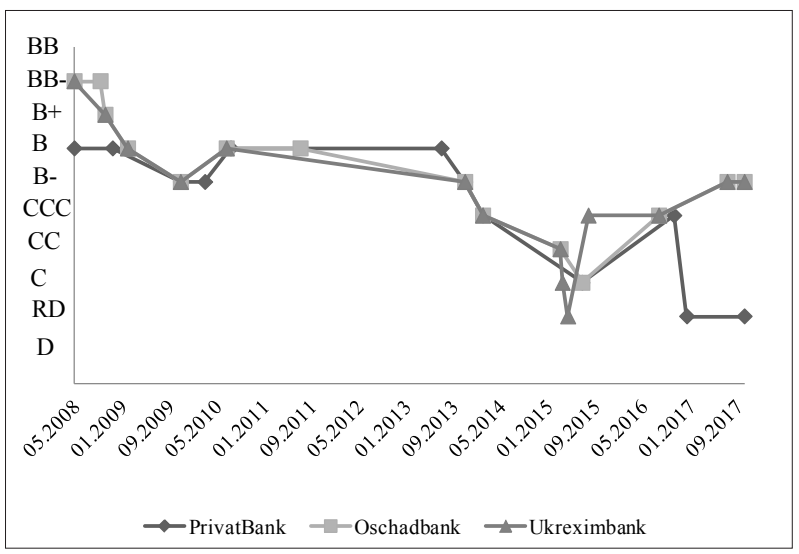

Fig. 2. Fitch Ratings development for PrivatBank, Oschadbank, and Ukreximbank, 2008-2017

Source: the author's own research based on banks' public information and Fitch Ratings (2017, July 25) 
stabilization of the economic situation while the recent downgrade of PrivatBank to $\mathrm{RD}$ in the last quarter of 2016 can be attributed to the bank's individual financial difficulties (see Figure 2).

\section{Methodical approaches}

This research applies a qualitative comparative analysis to a range of indicators of the health of the Ukrainian economy and its banking sector. Quantitative data for this review has been collected from a number of sources, predominantly Bloomberg, Fitch Ratings, and National Bank of Ukraine. Three major Ukrainian banks PrivatBank, Oschadbank, and Ukreximbank were taken for the analysis. To understand the credit quality assessment, taking Fitch's systematic as an example, the long-term issuer default ratings are informed by a combination of two elements, namely (i) the individual bank's viability rating and (ii) the support rating from an institutional and/or sovereign level (Fitch Ratings, 2014, April).

Credit ratings are therefore inherently linked to the respective sovereign rating. Fitch on April 28, 2017, affirmed November 11, 2016, long-term foreign- and local-currency issuer default ratings for Ukraine at "B-" with having a stable prognosis. Fitch upgraded the Ukrainian state from CCC level, which was indicating that default was an actual possibility, noting that chance for meeting financial commitments depended on improving the economic situation. During the same time, Fitch upgraded Oschadbank and Ukreximbank from CCC rates to B-, while PrivatBank was downgraded to $\mathrm{RD}$, which according to Fitch can indicate default on financial obligations that has not yet led to filing for bankruptcy or any other winding-up process, thus remaining in operations. The PrivatBank downgrade can also reflect the nationalization by the government of Ukraine in December 2016, as a result of the National Bank of Ukraine investigation of PrivatBank's capital deficit.

\section{Findings}

The analysis showed that concerning Ukrainian banks, the international ratings by Fitch, S\&P and Moody's are based on several key drivers, which inform the agencies' current risk assessments, as well as conditions for future rating actions. In the research, the following credit rating drivers for Ukrainian banks were identified.

Sovereign risk. According to IMF (2015, August 4) data, 51 banks representing ca $22 \%$ of the Ukrainian banking system's total assets have fallen into insolvency since the beginning of 2014, 42 of which were in liquidation. Furthermore, several banks were engaged in restructuring their foreign currency liabilities to free up capital.

The research showed, as can be seen in Figure 3, the yield on short-dated Ukrainian government bonds has increased dramatically followed by the corresponding CDS, indicating the market's assessment of the stressed state of the country's government. The 2-year and 5 -year government bond yields in USD have similar development trends as 2-year and 5-year CDS, which spiked in the spring of 2015, indicating the market's assessment of the country's critical economic and governmental state. During this time conventional yield structures inversed with 2-year government bond yield in USD trading at significantly higher yields than 5 -year government bond yield in USD. While longer maturity instruments should usually trade at a higher rate, this development clearly reflected the public market scepticism of the Ukrainian government's shortterm solvency outlook. Yields reached a peak of around of $80 \%$ at the end of March 2015; one week after the Ukrainian Parliament approved the list of regions on the special status of Donbas on the 17 of March, as was discussed at the Minsk II.

As of today, government bond yields returned to normal patterns with the 5-year government bond yield in USD exceeding that of the 2 -year yield by ca $130 \mathrm{bps}$.

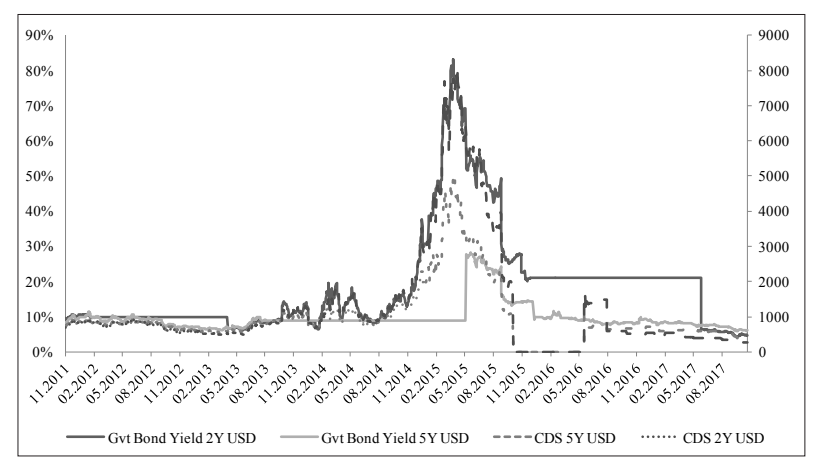

Fig. 3. Ukraine's $2 \mathrm{Y}$ and $5 Y$ government bond yield in USD and 2Y and 5Y CDS development, 2011-2017

Source: the author's own research based on the Bloomberg data (2017)

After the Minsk-II agreement, the security situation in the east of the country has somewhat stabilized, however, the remaining uncertainty and potential for renewed military conflict is still a key factor in the rating agencies' sovereign risk assessment given the strongly negative impact a renewal of the conflict would have for the economy as a whole. The development and presumed connection between the changes in the Ukrainian banks' ratings and the economic state of the country can be observed in Figure 4, where the waves of the real GDP decline are parallel to the ratings' downgrade of the selected banks, especially in 20082010 and 2014-2016.

Ukraine's fiscal situation is also heavily strained with the government continuing to post a budget deficit (NBU, 2017).

Between 2012 and 2014, Ukraine's government debt more than doubled to 1.1 trillion UAH (71\% of GDP) with the Ukrainian National Bank expecting 


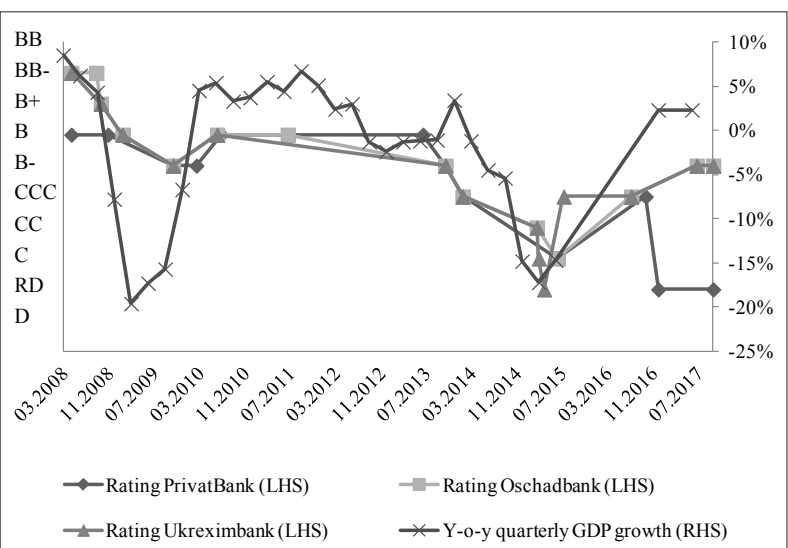

Fig. 4. Fitch Ukrainian banks ratings vs. quarterly real GDP development, 2008-2017

Source: the author's own research based on banks' public information, Fitch Ratings (2017, July 25), and Bloomberg data (2017)

debt levels to rise. Moody's (2015, July 10) stated that the government in order to deal with the deficit and be able to refinance the debt falling due became dependent on increasingly costly new local market borrowings, on borrowings from IMF, MDBs, as well as bilateral creditors. But even despite new attracted loans, the government is still running out of funding, which led to the additional currency volume issue.

The increase in money supply has put pressure on the hryvnia exchange rate and led to a sharp increase in interest rates by the Ukrainian National Bank. The main refinancing rate stood at 29\% at the end of August 2015, while inflation reached levels of around 55\% in July 2015, 39\% for the period of January-July 2015 (NBU, 2015, June).

To avoid an imminent default, the Ukrainian government has been engaged in negotiations with the IMF and private bondholders regarding the restructuring of certain government issued or guaranteed foreign currency obligations. At the beginning of September, bondholders representing a nominal amount of $18 \mathrm{bn}$ USD, or around a half of Ukraine's sovereign foreign debt at the time, reached an agreement with the Ukrainian state approving a $20 \%$ haircut on their debt and a maturity extension until 2018. In return, the state agreed to an interest rate uplift and warrants linked to country's GDP development for bondholders.

The participation of bondholders through debt relief has been a key demand by the IMF towards the Ukrainian government to allow the further release of IMF loans to the country under the 17.5 bn USD program. Given the country's limited access to other funding sources, the IMF loans are seen as vital by the rating agencies. Another 1.7 bn USD loan release was agreed by IMF on the 31 of July 2015 (IMF, 2015, July 31). The targets agreed with the IMF include providing 15 billion USD in public-sector financing, a public and publicly guaranteed debt-to-GDP ratio of below $71 \%$ of GDP by 2020; and holding budget financing needs at an average of $10 \%$ of GDP and below an annual maximum of $12 \%$ from 2019 to 2025 (IMF, 2015, August 4).

Any unexpected misses of economic targets set by the government and agreed with the IMF would put the release of further funding into question, make additional restructurings necessary, and cause downward pressure on the country's credit default assessment. As an example, Moody's (2015, July 10) also stated that Ukrainian economic and external position was weaker than had been expected and that the unstable political situation and difficulties in executing the program's conditions could lead to changes in the program and the halt of IMF disbursements.

Currently, the Ukrainian government is being rated at "B-" with a stable outlook. It is believed that further expected projections regarding the correlation of the general government debt to GDP will depend on the Ukraine's currency exchange rate, as well as the term of its trade, and also on the situation's development in the Eastern Ukraine. Any further downgrades of the sovereign rating of Ukraine would translate directly into consequences for Ukrainian banks. Also, the ability and willingness of the state or major shareholders to provide support to the banks through funding are seen as a critical factor in the assessment of individual ratings.

Capital position and asset quality. If one compares the development of the ratings by the three major Ukrainian banks to the development of the Tier 1 capital ratio, a key indicator of the financial health of the banks, the action of the rating agencies developed analogously indicating its role as a strong influencing factor. This relationship has particularly been visible in recent past starting from mid2013. When Tier 1 capital ratio of the Ukrainian banks reached their low point at $5.5 \%$, the ratings of the major banks covered by Fitch also reached their lowest points in the last years: $\mathrm{RD}$ for Ukreximbank due to ongoing restructuring of their foreign currency denominated debt, $\mathrm{C}$ for PrivatBank and Oschadbank, who were also in restructuring negotiations (see Figure 5).

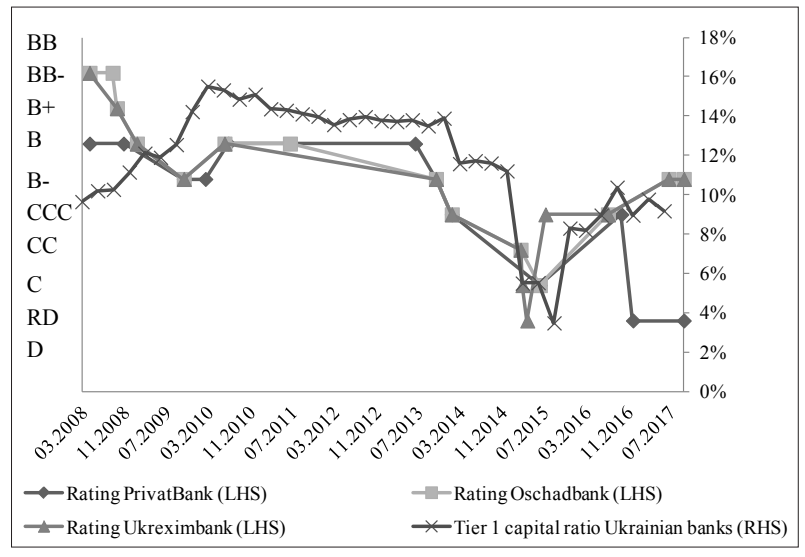

Fig. 5. Fitch Ukrainian banks ratings vs. Tier 1 capital ratio development of Ukrainian banks, 2008-2017

Source: the author's own research based on banks' public information, Fitch Ratings (2017, July 25) and National Bank of Ukraine data (2017) 
Unsurprisingly, the negative development of the Ukrainian economy has had a strong impact on banks' loan portfolio qualities and capital positions. According to data by the Ukrainian National Bank (2017), the nonperforming loan ratio for the banking sector reached over $24 \%$ in June 2015, while the industry average Tier 1 capital ratio fell to around 5\%. Furthermore, the regulatory capital adequacy ratio for the entire Ukrainian banking system (including insolvent banks) almost halved from $15 \%$ in January to $8 \%$ in August 2015 , even less than the lows of around 13\% during the global financial crisis in 2008 and below the regulatory $10 \%$ minimum.

A first asset quality review of the 35 largest Ukrainian banks conducted by the National Bank in 2014 identified additional capital needs of 66 bn UAH, or around $4 \%$ of the country's 2014 GDP, for the country's banking system (NBU, 2014, October 10). Until June 2015, 5 banks did not meet the increased capital requirements set as a result of the stress test and were declared insolvent (IMF, 2015, August 4).

As agreed in the MoU with the IMF in February 2015, a second asset quality review and subsequent stress test based on March 2015 numbers were conducted. Based on the individual banks' stress test performance and their ability to recapitalize, rating agencies factored in these developments into their latest assessments.

The impact of declining credit quality on operational performance was also frequently discussed. In April 2015, S\&P (2015, April 21) noted regarding PrivatBank that the agency was forecasting that the bank's profitability in 2015-2016 would decline significantly, which would be lower than that of its international peers, as a result of creating bigger volumes of additional provisions.

Determinants of asset quality as viewed by rating agencies include the individual asset mix of a bank. The Ukrainian government has committed in its $\mathrm{MoU}$ with the IMF to increase the transparency of related party lending and to effectively enforce the limitations in place. The National Bank of Ukraine for the first time published data on this in July 2015 and, as of August 2015, the maximum credit exposure to related parties for the total Ukrainian banking system was reported at 20\% (NBU, 2017).

According to the IMF (2015, August 4), the country's largest banks had their portfolios reviewed and measures are planned to dissolve any lending positions, which do not comply with the newly set limit of $25 \%$ for related party lending and to monitor their developments going forward.

Several banks have been negotiating with their creditors to restructure their foreign currency debt exposures. Notably, bondholders in Oschadbank and Ukreximbank agreed to a maturity extension of their 1.5 bn USD and 1.2 bn USD exposures, respectively, in return for a margin uplift on the debt.
However, the strong dependency on emergency liquidity and exposures to the volatile economic environment will continue to keep most banks from surpassing the Ukrainian government's ratings.

Funding and Liquidity. Another effect of the ongoing economic downturn in the country has been strong volatility in banks' short-term funding. Nominal demand deposits of households in local currency went down by $20 \%$ between the beginning of 2014 until the middle of 2015 and foreign currency deposits fell even more dramatically by over 50\% (USB Research, 2015, August 17). While the situation has to some extent stabilized in mid-2015, the agencies continue to see low investor confidence as a key weakness.

As an indicator of bank liquidity, the stark increase in the loan-to-deposit ratio of the Ukrainian post-2008 financial crisis, indicating higher leverage and deposit outflows, moved in parallel with decreasing credit ratings with a current loan-to-deposit ratio around 1.18 times (see Figure 6).

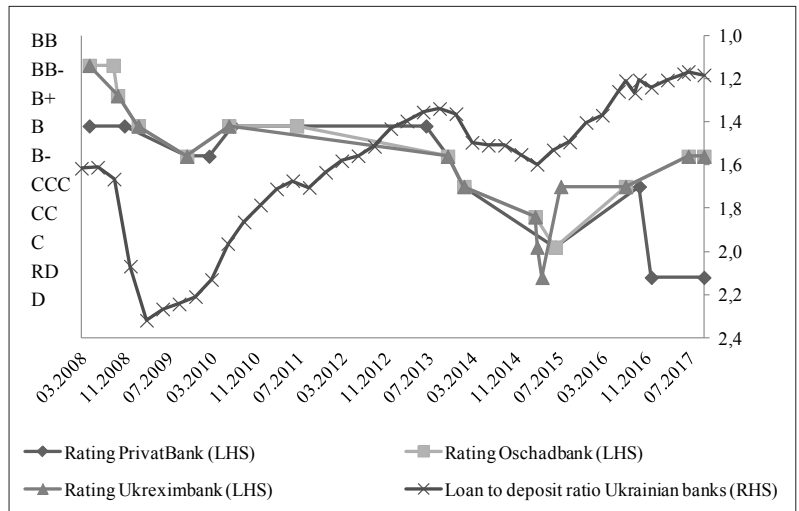

Fig. 6. Fitch Ukrainian banks ratings vs. loan to deposit ratio development of the Ukrainian banks, 2008-2017

Source: the author's own research based on banks' public information, Fitch Ratings (2017, July 25) and National Bank of Ukraine data (2017)

Moody's (2015, July 10) stated that Ukrainian banks continue to face significant liquidity risks and that the confidence of depositors still has to stabilize. In the first quarter of 2015, following strong withdrawals in 2014, Ukraine's banking system was hit by $5 \%$ of local-currency deposits and $13 \%$ of foreign-currency deposits decrease. Ukrainian banks faced challenges paying back their international borrowings that were due in 20152016, which required further distressed exchanges in order to extend maturities.

Deposit outflows and the strong devaluation of the hryvnia have led to an erosion of bank liquidity. In 2015 alone, the Ukrainian National Bank provided over 5 bn UAH in emergency liquidity assistance to the banking system, notably including PrivatBank and Ukreximbank, and a maturity extension on past loans was granted to recipients (NBU, 2017). 
In its note on PrivatBank from July 2015, S\&P opined that it viewed the PrivatBank's liquidity as weak compared to moderate. Agency's evaluation was based on the bank's strong dependence on the National Bank of Ukraine for the liquidity assistance to tackle the problem of the continuing withdrawal of deposits. S\&P also stated that it believed that the planned Eurobond restructuring could weaken the confidence of investors (Interfax-Ukraine, 2015, July 10).

From the rating agencies' perspective, the sustained provision of liquidity by the Ukrainian National Bank to the banking system, as well as short-term capital controls, has been of key importance for stabilizing the banking sector as a whole.

Free access to capital markets and the successful raising of capital are also seen as prominently positive factors for the individual banks' liquidity positions. However, the current environment remains very difficult. As of October 2017 cost of loans is around 14.8\% in domestic currency and $8 \%$ in foreign currency, while costs of term deposits are $9.4 \%$ and $2.6 \%$ in national and foreign exchanges correspondingly. An average weighted interest rate on interbank credit market is at $11.7 \%$ level (NBU, 2017).

The impact of the complex interplay of deposit flows, inflation and interest rate development, as well as government solvency, will be a key determinant for rating agencies in their credit strength assessments for individual banks.

Exchange rate. Another deciding factor is local currency stability. The hryvnia exchange rate against the main currencies dramatically reduced in 2015 with the rate against the USD decreasing by $40 \%$ from January to September 2015. Given that around 50\% of total loans to customers and other financial institutions in the country's banking system are denominated in foreign currencies, according to data from Ukrainian National Bank per July 2015, hugely negative implications become apparent (NBU, 2017). These developments put considerable strain on banks' foreign currency reserves.

As shown in Figure 7 the dramatic decrease of the UAH/USD exchange rate starting at the end of 2013, mirroring a strong increase in inflation and overall worsening state of the Ukrainian economy and the banking sector, in particular, has been reflected in the banks' ratings. Currently, Ukrainian two major banks' ratings are $\mathrm{B}$ - and PrivatBank hovering around the default level, while the exchange rate is trading near its recent historical low of $26 \mathrm{UAH} / \mathrm{USD}$.

S\&P (2015, August 28) noted that in February 2015 hryvnia has been officially floated, and its exchange rate was supported by a drastic increase in the refinancing rate and rigorous control over the currency. This control included the prohibition of the foreign currency exchange sales by individuals larger than $3,000.00$ hryvnias, as well as $15,000.00$ hryvnias

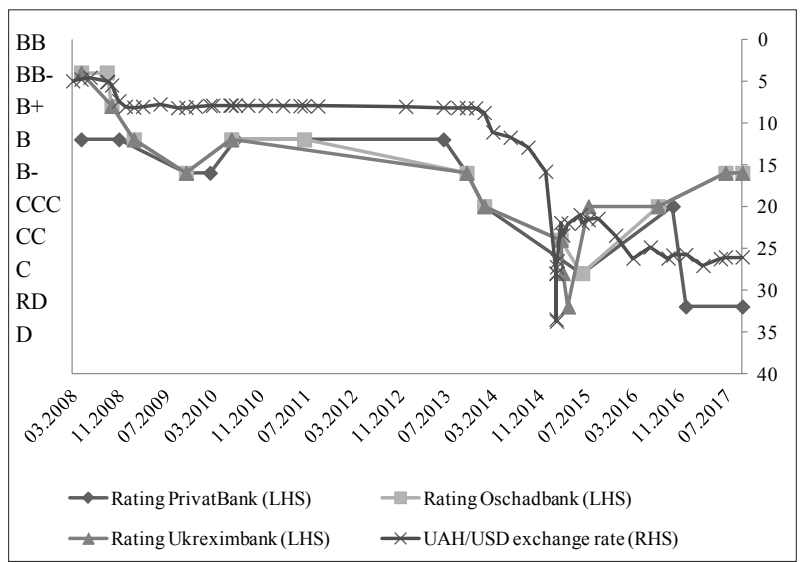

Fig. 7. Fitch Ukrainian banks ratings vs. UAH/USD exchange rate development, 2008-2017

Source: the author's own research based on banks' public information, Fitch Ratings (2017, July 25) and National Bank of Ukraine data (2017)

on deposit payments in foreign currencies. Another control measure was restrictions on banks' foreign exchange purchases for own accounts, the obligatory sale of $75 \%$ of exporter's foreign receivables in exchange for hryvnias, and more severe control of importers.

Refinancing of foreign currency debt has, therefore, become extremely challenging for Ukrainian banks. To address this, as mentioned above, the country's largest private banks, banks controlled by the government, as well as the government itself, have been engaging in negotiations with lenders to restructure their foreign currency Eurobonds, mainly seeking to reduce debt and interest burdens through haircuts or the extension of maturities. The success of these efforts is closely monitored by the rating agencies and has both short- and long-term implications for the institutions' ratings.

\section{Conclusions}

The Ukrainian banking sector is currently facing a highly challenging environment reflected in a volatile economy, reduced capital cushions, increased reliance on state funding to counter dwindling liquidity, as well as a decrease of credit quality across the market. Credit rating drivers for Ukrainian banks that were identified by this research to pose a key influence are: 1) sovereign risk; 2) capital position and asset quality; 3) funding and liquidity; 4) exchange rate.

All these aspects are under consideration by the rating agencies and previously led to steady downgrades of Ukrainian banks that indicated heightened default expectations. Analogously, the agencies mostly saw a government default as very likely. The Ukrainian government's solvency and its ability to restructure its debt, receive support and debt relief from its creditors, and ability to control the political situation in the country will be the key factors to stabilize the system. 
Currently, Ukraine is on a road to a successful restructuring ahead, which also showed in improving credit ratings for banks. Until this journey is completed, the faith of the Ukrainian banking system is intrinsically linked to the country's economic and political progress, as well as creditors' confidence.

\section{References:}

Bloomberg. (2017). Data: 1). 2-year and 5-year USD Ukrainian governmental bond yield, 2-year and 5-year USD CDS from November 2011 to October 2017; 2). Ukraine's GDP development from March 2008 to October 2017. Retrieved October 24, 2017 from Bloomberg terminal.

Fitch Ratings. (2017, July 25). Fitch Affirms Ukreximbank and Oschadbank at 'B-'/Stable; Upgrades VRs. DoddFrank Rating Information Disclosure Form. Retrieved October 24, 2017 from: https://www.fitchratings.com/ site/dodd-frank-disclosure/1026966

Fitch Ratings. (2014, April). Introducing Ratings Navigator for Banks. Fitch Ratings Navigators. Retrieved October 24, 2017 from: http://image.fitchemail.fitchratings.com/lib/fe9812717765027d72/m/1/ NavigatorPromotionalMaterial20.pdf

IMF. (2015, August 4). First Review Under The Extended Arrangement-Press Release; Staff Report; And Statement By The Executive Director For Ukraine. IMF Country Report No. 15/218. Retrieved October 24, 2017 from: https://www.imf.org/external/pubs/ft/scr/2015/cr15218.pdf

IMF. (2015, July 31). IMF Executive Board Completes First Review of Ukraine's EFF and Approves US\$1.7 Billion Disbursement. IMF Press Release No. 15/364. Retrieved September 18, 2015 from: http://www.imf.org/external/ $\mathrm{np} / \mathrm{sec} / \mathrm{pr} / 2015 / \mathrm{pr} 15364 . \mathrm{htm}$

Interfax-Ukraine. (2015, July 10). S\&P downgrades PrivatBank to 'CC' on invitation to creditors to extend maturity of eurobonds. Retrieved October 24, 2017 from: http://en.interfax.com.ua/news/economic/277140.html

Interfax-Ukraine. (2015, April 21). S\&P lowers PrivatBank's long-term rating to 'CCC-' on increased economic and sovereign risks. Retrieved October 24, 2017 from: http://en.interfax.com.ua/news/economic/261517.html

Moody's. (2014, December 19). Ratings Report: Ukraine, Government of. New York, Moody's. Retrieved October 24, 2017 from: https://www.moodys.com/credit-ratings/Ukraine-Government-of-credit-rating-600037040

Moody's. (2015, July 10). Moody's: Outlook stays negative for Ukraine's banking system. Moody's Investors Services. Retrieved September 18, 2015 from: https://www.moodys.com/research/Moodys-Outlook-staysnegative-for-Ukraines-banking-system--PR_329781

National Bank of Ukraine (2017). Statistics: 1). Macroeconomic indicators; 2). Monetary and financial statistics; $3)$. Financial Soundness Indicators; 4). Banking System Indicators; 5). Data from the financial statements of the Ukrainian banks; 6). Implementation of prudential ratios by the entire Ukrainian banking system in 2015; 7). Key performance indicators of banks; Information materials: 1). Information on loans with a maturity of over 30 days granted to the Ukrainian banks by the National Bank of Ukraine in 2015. Retrieved October 24, 2017 from: https://bank.gov.ua/control/en/publish/article?art_id=67604\&cat_id=37801

NationalBankofUkraine.(2015,June).InflationReport.RetrievedOctober24,2017from:http://www.bank.gov.ua/ doccatalog/document?id=19007320

National Bank of Ukraine. (2014, October 10). Oleksandr Pysaruk: In one or two years from now, we must have a revamped banking system. Retrieved October 24, 2017 from: http://www.bank.gov.ua/control/en/publish/ article?art_id=11345111\&cat_id=92516

S\&P Ratings Services. (2015, August 28). Research Update: Ukraine Long-Term Foreign Currency Rating Affirmed At 'CC'; Outlook Remains Negative. New York, NY: Standard \& Poor's Ratings Services. Retrieved October 24, 2017 from: http://www.standardandpoors.com/en_US/web/guest/article/-/view/sourceId/20013397

USB Research. (2015, August 17). Ukrainian Capital Markets Weekly. Kiev: BNP Paribas Group, pp.3-6.

\section{Светлана ПОКРАСЬОН}

\section{ЗДОРОВАЯ ДОЗА ПЕССИМИЗМА? ВЛИЯНИЕ УКРАИНСКОЙ ЭКОНОМИКИ НА КРЕДИТНЫЕ РЕЙТИНГИ БАНКОВСКОГО СЕКТОРА}

Аннотация. Целью исследования является определение влияния экономического развития страны на кредитный рейтинг её банковской системы. Нестабильность и неоднозначное геополитическое положение Украины усложняют любые прогнозы касательно её экономического развития. В то же время, масштабная реструктуризация всех секторов экономики стала необходимым минимумом для реформирования страны и достижения международных стандартов. Интересно посмотреть, как именно эти международные стандарты, представленные оценкой рейтинговых агентств, оценивают Украину и, в частности, ее банковский сектор. Методология включает в себя анализ трех основных украинских банков - ПриватБанка, Ощадбанка и Укрэксимбанка с использованием системы оценки качества кредитов Fitch. Сравнительный анализ проводился с использованием коэффициента капитала 1 уровня украинских банков, квартального роста ВBП, индекса изменения потребительских цен (ИПЦ), обменного курса UAH/USD, показателя соотношения 
кредитов и депозитов украинских банков, 2-летних и 5-летних доходных государственных облигаций, 2-летних и 5-летних кредитных дефолтных свопов. Результаты показывают, что основными драйверами кредитного рейтинга для украинских банков, которые оказывают основное влияние, являются: обменный курс; финансирование и ликвидность; капитализация и качество активов; суверенный риск. Исследование показало, что доходность 2-летних и 5-летних государственных облигаций в долларах США, 2-летних и 5-летних кредитных дефолтных свопов имела схожую тенденцию развития. Доходность краткосрочных украинских государственных облигаций увеличилась параллельно с соответствующими кредитными дефолтными свопами, что свидетельствует о рыночной оценке напряженного состояния правительства и экономики страны. Кроме того, традиционные структуры доходности отображали обратную природу с доходностью 2-летних правительственных облигаций в долларах США с значительно более высокой доходностью, чем доходность 5-летних государственных облигаций в долларах США. Хотя более долгие инструменты погашения обычно должны торговаться по более высоким ставкам, такое развитие могло бы отразить скептицизм на публичных рынках в отношении краткосрочной платежеспособности украинского правительства. Более пристальный взгляд на коэффициент капитала 1-го уровня, который считается ключевым показателем финансового состояния банков, выявил аналогию развития между ним и рейтингами трёх крупных украинских банков, указав на то, что коэффициент капитала 1-го уровня есть сильным влияющим фактором. Соотношение кредитов и депозитов в качестве индикатора ликвидности банка перемещалось параллельно с понижением кредитных рейтингов. Сильное снижение обменного курса гривны / доллара отразилось на сильном увеличении инфляции. Общее ухудшение состояния украинской экономики также отразилось на рейтингах крупных банков. Практическое значение. Соотношение этих факторов актуально для менеджеров банков и инвесторов, которые могут использовать индикаторы финансового рынка для прогнозирования и планирования своих возможностей для ведения бизнеса. Аналогичным образом, академические исследователи могут продолжить работу над этим исследованием, чтобы прибавить к литературе обзоры суверенных долговых кризисов по конкретным странам и их влияние на национальные банковские системы. Значение/оригинальность. Это исследование показывает, что ухудшение финансовых показателей финансовой системы Украины, измеряемое доходностью государственных облигаций, а также кредитными дефолтными свопами, и экономический спад в стране, сопровождаются снижением кредитных рейтингов местных банков. 